\title{
MACIEJ SMOLAK
}

\section{O SPRAWCY DZIAŁANIA I ODPOWIEDZIALNYM DZIAŁANIU U ARYSTOTELESA}

Słowa kluczowe: cnota charakteru, człowiek najwyższej próby, decyzja, piękno, odpowiedzialność

Keywords: decision, fine, man of the highest order, responsibility, virtue of character

\section{Wstęp}

Arystoteles wprawdzie nie posługuje się terminem „odpowiedzialność", ale z tego nie wynika, że problematyka odpowiedzialności nie pojawia się w jego Etykach. Świadczy o tym na przykład uwaga otwierająca pierwszy rozdział trzeciej księgi Etyki nikomachejskiej $(E N)^{2}$, w której Arystoteles

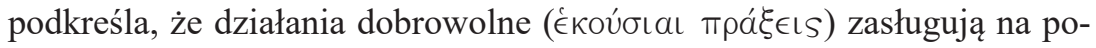

* Maciej Smolak - doktor w Zakładzie Etyki w Instytucie Filozofii UJ, obecnie zajmuje się teorią przyjemności u Arystotelesa, a także dydaktyką filozofii i interaktywnymi metodami nauczania filozofii.

Address for correspondence: Jagiellonian University, Institute of Philosophy, Grodzka 52, 31-044 Kraków. E-mail: m.smolak@iphils.uj.edu.pl.

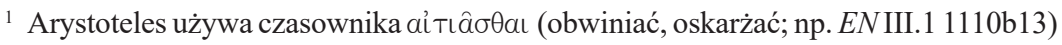
oraz przymiotnika alтıos (winien, oskarżony; np. EN III.5 1113b24).

2 Jak zaznacza Hursthouse (1984, s. 252), panuje powszechna tendencja, aby EN III.1 rozważać wyłącznie pod kątem zagadnienia moralnej i prawnej odpowiedzialności. 


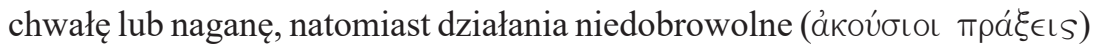
są wybaczalne, a niekiedy mogą budzić nawet litość (1109b31-32) .

Warto dodać, że we wspomnianej uwadze Arystoteles mówi nie tylko o działaniach, lecz również o reakcjach afektywnych (тá $\theta \eta^{4} ; E N$ III.1 1109b30), charakterystycznych dla tej części duszy, która jest alogiczna i zdolna do słuchania nakazów rozumu. Tymczasem zastosowanie terminu „dobrowolny” w stosunku do takich reakcji może budzić zastrzeżenia, ponieważ jak się wydaje, nie jest tak, że wywołujemy je w sobie dobrowolnie ${ }^{5}$. Nie można na przykład dobrowolnie się przestraszyć, ponieważ strach odczuwamy nie dlatego, że sami go wytworzyliśmy, lecz dlatego, że ktoś lub coś go w nas wywołało ${ }^{6}$. Z drugiej jednak strony, skoro cnota charakteru dotyczy działań, pragnień, uczuć oraz doznań związanych z rzeczami przyjemnymi i przykrymi (por. np. EN II.3 1104b13-15), a ocena zachowania człowieka jest zasadna przy założeniu, że jest ono dobrowolne, to oddawanie

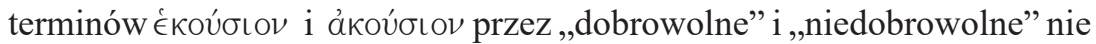

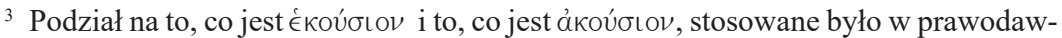

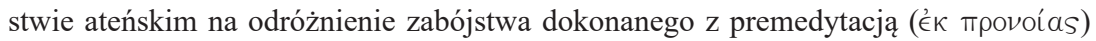
od nieumyślnego spowodowania śmierci. W codziennym użyciu oba terminy miały dwa podstawowe znaczenia - „umyślne-nieumyślne” i „ochotne-nieochotne”. Tak więc w czasach Arystotelesa funkcjonowały dwa paradygmaty, według których

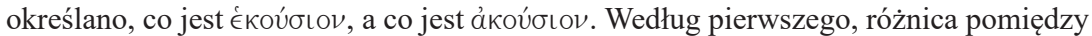

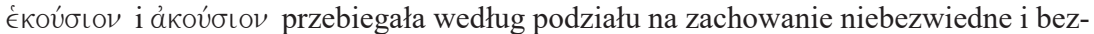
wiedne. Według drugiego, różnica przebiegała według podziału na zachowanie chciane i niechciane. Oba paradygmaty nie dostarczają jednak jednoznacznych dystynkcji na

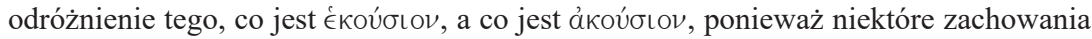

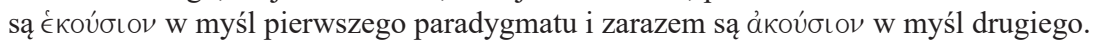
Na przykład, przekazanie okupu szantażyście jest działaniem, które w myśl pierwszego

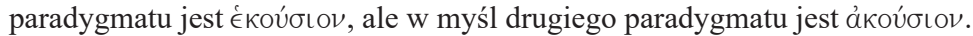

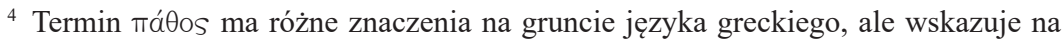
to, co reaktywne. W tym kontekście chodzi przede wszystkim o alogiczne poruszenia

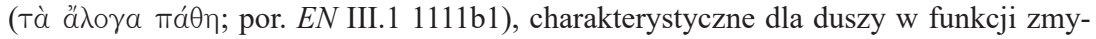
słowo-orektycznej, a więc o pragnienia, uczucia lub doznania.

5 Por. np. Moline (1989, s. 285).

6 Jak zauważa Arystoteles w EN V.8 1135b25-27, ,czyny z gniewu ('́̌ $\theta v \mu \circ \hat{)}$ słusznie ocenia się jako nie dokonane z premedytacją (oủk ék Tpovoías), ponieważ w takich sy-

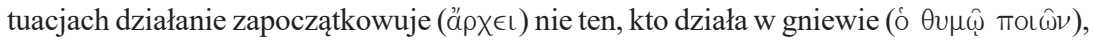

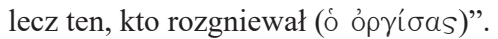


jest pozbawione podstaw ${ }^{7}$. Ponadto trzeba pamiętać, że gdy Arystoteles używa w swoich wykładach terminów zaczerpniętych z języka potocznego, zazwyczaj dokonuje ich reinterpretacji i przypisuje im znaczenia techniczne.

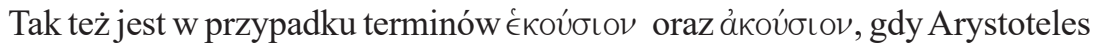
wiąże je z działaniami, ale także z reakcjami afektywnymi, zasługującymi na pochwałę, naganę lub usprawiedliwienie.

Należy podkreślić, że odpowiedzialność w rozważaniach Arystotelesa ma przede wszystkim charakter odpowiedzialności rozumianej negatywnie, czyli w sensie imputacji ${ }^{8}$. Świadczyć o tym może podjęte przez Arystotelesa badanie, którego celem jest wyjaśnienie, kiedy działanie jest działaniem dobrowolnym, a kiedy jest ono działaniem niedobrowolnym ${ }^{9}$. Z kolei takie badanie pozostaje w ścisłym związku z ustaleniem warunków, jakie muszą być spełnione, aby człowiek był sprawcą działania, a w konsekwencji mógł za nie odpowiadać. $Z$ tego jednak, że ktoś jest sprawcą działania i może być z jego powodu pociągnięty do odpowiedzialności, nie wynika, że jego działanie jest działaniem odpowiedzialnym. Nie każde bowiem działanie, które może być przypisane sprawcy, jest działaniem odpowiedzialnym według Arystotelesa.

Aby więc odpowiedzieć na pytanie, które działanie jest działaniem odpowiedzialnym u Arystotelesa, przeprowadzam dwuetapowe rozważanie. W pierwszym etapie wykazuję, w oparciu o kryterium przymusu, które działania są działaniami niedobrowolnymi, czyli również tymi, za które podmiot działający nie może ponosić żadnej odpowiedzialności. Następnie przechodzę do charakterystyki działań mieszanych i podpierając się nią, określam warunki, jakie muszą być spełnione, aby człowiek był sprawcą działania, a w konsekwencji ponosił za nie odpowiedzialność. W gruncie rzeczy, tylko działanie autor agendi może spełniać wymogi nałożone na działanie odpowiedzialne w ujęciu Arystotelesa. W drugim etapie przechodzę do wyjaśnienia, jak rozumieć wyrażenie ,decydować się na działanie zgodne z cnotą charakteru z powodu niego samego". Wydaje się bowiem, że według Arystotelesa działanie jest dopiero wtedy odpowiedzialne, gdy

${ }^{7}$ W podsumowaniu EN III.1 1111b1-3 Arystoteles podkreśla, że „,działania, których

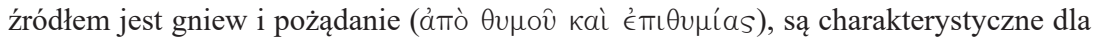
człowieka, i dlatego byłoby czymś dziwnym uważać je za niedobrowolne (ảkoúøı $\alpha$ )".

${ }^{8}$ Por. np. Bondeson (1974, s. 59).

9 Nie do przecenienia analizy dotyczące zagadnienia dobrowolności i niedobrowolności w filozofii praktycznej Arystotelesa przedstawia Galewicz (2003). 
jest zgodne z cnotą charakteru i autor agendi przedsiębierze je z jego powodu. Przedstawiam trzy sposoby rozumienia przytoczonego wyrażenia i posiłkując się nimi, zarysowuję ostateczną odpowiedź na pytanie: „które działanie sprawcy jest działaniem odpowiedzialnym w ujęciu Arystotelesa?".

\section{Kiedy człowiek jest sprawcą działania}

Po wstępnej uwadze, że to, co niedobrowolne, jest wynikiem przymusu (ßíą; EN III.1 1110a1), Arystoteles przystępuje do próby określenia tego, co przymusowe (ßíaıov). W dalszej jednak części badania problematyzuje zagadnienie i przechodzi do rozważenia działań, które nazywa mieszanymi ( $\mu\llcorner\kappa т a i ̀ ~ \pi \rho a ́ \xi \in ı S ; 1110 a 11)$. Mieszany charakter działań wynika między innymi stąd, że ich ostateczna zasada znajduje się w podmiocie działającym, ale obecność i oddziaływanie zewnętrznej zasady nie pozostaje bez wpływu na ich realizację.

\section{To, co przymusowe}

Przystępując do wyjaśnienia tego, co przymusowe, Arystoteles stwierdza, co następuje:

Przymusowe jest to, czego zasada (ảpxи́) jest zewnętrzna, [ale] taka,

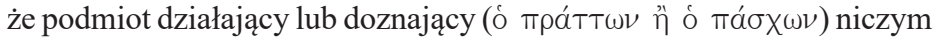
się do niej nie przyczynia - na przykład, jeśli wiatr gdzieś go uniósł lub ludzie, którzy mają nad nim władzę (1110a1-4).

W podanej wykładni przymusu, wyrażenie ,podmiot działający” może być mylące, ponieważ podmiot, którego spotyka opisany przymus, nie jest w ogóle sprawcą tego, co się dzieje ${ }^{10}$. To, co zachodzi, nie może być działaniem podmiotu, ponieważ: i) zasada działania nie znajduje się w podmiocie, lecz poza nim; ii) podmiot nic się nie dokłada do zewnętrznej zasady.

Punkt i) zwraca uwagę na to, że zasada, która znajduje się poza podmiotem, jest przede wszystkim na zewnątrz w stosunku do jego ciała.

${ }^{10}$ Zwracają na to uwagę między innymi Gauthier i Jolif (w: Aristote, 1958, s. 55) w swoim przekładzie $E N$ : „Est fait par contrainte l'acte dont le principe est extérieur au sujet, à condition toutefois que ce principe soit d'une nature telle quel'agent, - ou pour mieux dire le patient, - n'y concoure en rien". 
Wskazują na to przykłady zewnętrznej zasady podane przez Arystotelesa $-\mathrm{z}$ jednej strony wiatr, $\mathrm{z}$ drugiej strony inni ludzie, którzy stosują przemoc wobec podmiotu. W 1110a15-16 Arystoteles podkreśla, że działanie jest dobrowolne, kiedy zasada ruchu części ciała biorących udział w danym działaniu, znajduje się w podmiocie, a nie poza nim. Można więc zasugerować, że ciało podmiotu jest niejako ostateczną podstawą jego odrębności w stosunku do tego wszystkiego, co nim już nie jest ${ }^{11}$.

Punkt ii) podkreśla, że sprawstwo leży w całości po stronie zewnętrznej zasady - podmiot niczym się nie przyczynia do tego, co się dzieje. Z tego punktu widzenia przykład z wiatrem wymaga dookreślenia, ponieważ jeśli żeglarz dąży do pomyślnego zakończenia swojej żeglugi, to nie sposób o nim powiedzieć, że niczym się nie przyczynia do zewnętrznej zasady, nawet jeśli zdarzyło się, że ostatecznie dopłynął nie tam, gdzie zamierzał. Arystotelesowi chodzi więc raczej o sytuację przytoczoną w Metafizyce (Met) V.30, opisującą pasażera statku, który wyruszył w podróż do Syrakuz, ale w wyniku szalejącej burzy dotarł nie do Syrakuz, lecz na Eginę ${ }^{12}$. Idzie mu więc o taką sytuację, w której podmiot nie ma żadnego wpływu na przebieg wydarzeń. I bynajmniej nie dlatego, że nie podejmuje działania, ponieważ nie chce nic zrobić, lecz dlatego, że nic nie może zrobić w sytuacji, w jakiej się znalazł.

${ }^{11}$ W EN V.8 1135b1-2 Arystoteles zwraca uwagę na rzeczy wykonywane i doznawane przez nas, z których żadna nie jest jednak ani dobrowolna ani niedobrowolna. Ma tu na myśli nieuniknione procesy naturalne zachodzące w naszym organizmie, takie na przykład jak starzenie się czy umieranie (w podobnym duchu Arystoteles wypowiada się również w EN III.5 1113b26-30). Ponieważ zasadą procesów zachodzących w naszym organizmie

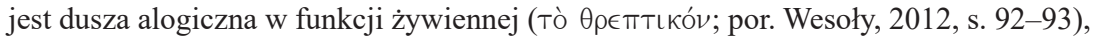
więc nasuwa się przypuszczenie, że z działaniem zewnętrznej zasady w stosunku do nas mamy do czynienia nie tylko wtedy, gdy taka zasada znajduje się poza nami w sensie na zewnątrz naszego ciała, lecz również wtedy, gdy jest ona poza nami w sensie na zewnątrz naszej duszy logicznej i alogicznej, lecz w funkcji zmysłowo-orektycznej. Bez względu jednak na to, czy takie przypuszczenie jest zasadne czy też nie, należy podkreślić, że nieuniknione procesy przynależne do naszej natury nie są przymusowe w rozumieniu EN III.1 1110a1-4.

12 Dodatkowym potwierdzeniem słuszności przekonania, że chodzi o sytuację opisaną w Met V.30 jest fakt, że ów ktoś, kto wbrew sobie przybył na Eginę, dostał się tam - jak zauważa Arystoteles - za sprawą gwałtownego wiatru lub przez to, że został uprowadzony przez piratów (1025a-27). Podane przyczyny przybycia podmiotu na Eginę odpowiadają wymienionym przykładom zasad zewnętrznych w EN III.1 (por. np. Gauthier i Jolif, w: Aristote, 1959, s. 172). 
Należy dodać, że w uwadze otwierającej EN III.1 Arystoteles zaznacza, że umiejętność odróżniania tego, co dobrowolne, od tego, co niedobrowolne, z jednej strony jest czymś koniecznym dla tych, którzy zajmują się cnotą charakteru, z drugiej zaś jest czymś pożytecznym dla tych, którzy zajmują się prawodawstwem (1109b32-34) ${ }^{13}$. Jest tak między innymi dlatego, że bez posiadania takiej umiejętności, pierwsi nie mogliby kształtować i oceniać ludzkich charakterów, drudzy zaś - nie mogliby wydawać sprawiedliwych wyroków ${ }^{14}$.

Gdy zasada zewnętrzna jest taka, że podmiot niczym się do niej nie przyczynia, to ocena działania, od strony prawnej, staje się bezprzedmiotowa i nie ma podstaw, aby zachowanie podmiotu karać lub ganić czy też nagradzać lub pochwalać. Prawodawcę nie będzie też interesowało w tym kontekście, czy to, co spotkało podmiot, budzi w nim awersję, ponieważ zdarzenie z jego udziałem zostało wywołane przez zewnętrzną siłę. Ponieważ w tych warunkach podmiot nie jest w ogóle sprawcą działania, więc nie może być prawnie odpowiedzialny za to, co się stało, i to bez względu na to, czy sprawiło mu to przykrość czy przyjemność.

Ci jednak, którzy zajmują się cnotą charakteru, będą zainteresowani, czy to, do czego doszło za sprawą działania zewnętrznej zasady, cieszy podmiot czy też go martwi. Wprawdzie to, co zachodzi w wyniku działania zewnętrznej siły, dzieje się zazwyczaj wbrew chęci podmiotu i nie bez przykrości. Któż bowiem akceptuje zadawany mu gwałt? Może jednak być tak, że podmiot będzie zadowolony z tego, co się dzieje na skutek działania zewnętrznej zasady ${ }^{15}$.

13 Na tej między innymi podstawie Hursthouse (1984) dochodzi do wniosku, że w EN III.1 Arystoteles jest zainteresowany przede wszystkim dalszą charakterystyką cnoty charakteru, a nie zagadnieniem moralnej czy prawnej odpowiedzialności (por. przyp. 2).

${ }^{14} \mathrm{~W}$ gruncie rzeczy, jedni i drudzy zajmują się cnotą charakteru, ponieważ jedni

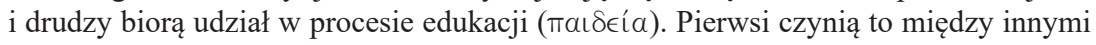
przez to, że troszczą się, aby ich wychowankowie uzyskali pełne zrozumienie, czym jest działanie zgodne z cnotą charakteru i dlaczego ma ono znaczenie z punktu widzenia prowadzenia wartościowego sposobu życia w sferze prywatnej oraz publicznej. Drudzy czynią to uczestnicząc w projektowaniu tó $ı$ s i ustanawiając prawa, które mają sprzyjać

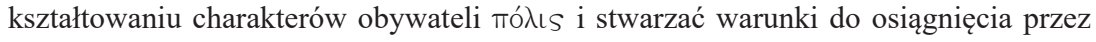
nich eudaimonii.

15 Galewicz (2003, s. 25) zwraca uwagę, że możliwość zachodzenia takich przypadków daje powód do przyjęcia koncepcji ,,przymusu akceptowanego”. Jeśli więc czyn pewnego podmiotu ma być w pełni przymusowy, to musi on być nie tylko spowodowany przez 
Przykładem przymusu akceptowanego może być opis zachowania wojownika płynącego na wyprawę wojenną, który nie chce brać udziału w bitwie morskiej, lecz ze strachu przed karą trwa na swoim posterunku ${ }^{16}$. Za sprawą szalejącego sztormu statek z wojownikiem znalazł się na tyłach wroga i cała załoga statku dostała się do niewoli. Ponieważ do zdarzenia doszło w wyniku działania zewnętrznej zasady, więc to, że wojownik nie uczestniczy w batalii, nie wchodzi w zakres tego, co jest dobrowolne. Nie można go zatem pociągać do odpowiedzialności za jego nieobecność podczas bitwy. Z drugiej jednak strony, ponieważ wojownik nie odczuwa przykrości z powodu nie uczestniczenia w batalii - wszak nie chciał w niej uczestniczyć - więc działanie zewnętrznej zasady przyjmuje z aprobatą.

Dla zajmujących się cnotą charakteru jest to wystarczająca wskazówka, że wojownik nie odznacza się cnotą męstwa w pełnym tego słowa znaczeniu

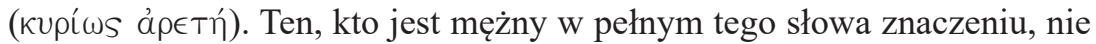
tylko zachowuje gotowość do walki, lecz jeśli trzeba, walczy czyniąc to ze

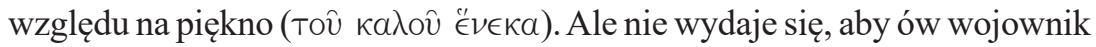

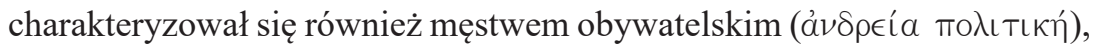
czyli męstwem powodowanym wstydem ( $\delta \iota^{\prime}$ ai $\left.\delta \hat{\omega}\right)$. Ten, kto odznacza się cnotą męstwa obywatelskiego, chce walczyć i wywiązuje się z nałożonych obowiązków żołnierskich, chociaż popełnia błąd w ocenie wartości cnoty charakteru - w tym wypadku cnoty męstwa - ponieważ nie uważa, że jest ona warta wyboru dla niej samej. Zachowanie wojownika zdaje się więc wskazywać raczej na to, że w ogóle brakuje mu cnoty męstwa. Wojownik, który najchętniej by nie walczył, nie odznacza się nawet cnotą męstwa obywatelskiego i z punktu widzenia oceny jego charakteru należałoby przyjąć, że jest on raczej tchórzliwy niż mężny ${ }^{17}$. Przykład ma więc walor

pewną zasadę zewnętrzną, lecz ponadto musi być niezgodny z wewnętrzną skłonnością podmiotu (s. 26). W rezultacie Galewicz (s. 28) dochodzi do wniosku, że Arystoteles posługuje się dwoma różnymi pojęciami czynów przymusowych: a) szerszym, w myśl którego czyn jest przymusowy, gdy posiada zasadę zewnętrzną, ale taką, do której podmiot niczym się nie przyczynia; b) węższym, które nakłada dodatkowy warunek, w myśl którego czyn jest przymusowy, gdy jest spełniany z niechęcią i nie bez przykrości.

${ }^{16}$ Por. Hursthouse (1984, s. 256).

${ }^{17} \mathrm{~W}$ EN III.8 Arystoteles wykazuje, że prócz męstwa w pełnym tego słowa znaczeniu i najbardziej do niego podobnego męstwa obywatelskiego, można wyróżnić jeszcze pięć innych form męstwa: powodowane strachem przed karą, powodowane gniewem oraz bazujące na rutynie, optymizmie lub ignorancji. Daje jednak do zrozumienia, że mają one niewiele wspólnego z męstwem w pełnym tego słowa znaczeniu. Wydaje się więc, że są 
edukacyjny, ponieważ jest przydatny w kontekście szacowania charakteru danego podmiotu, a także uchwycenia różnicy nie tylko między cnotą i wadą charakteru, lecz również między cnotą charakteru w formie wytrenowanego nabytku i cnotą charakteru w pełnym tego słowa znaczeniu ${ }^{18}$.

\section{Działania mieszane ( $\mu$ $\kappa$ таi $\pi \rho a ́ \xi \in ı$ S)}

Arystoteles problematyzuje zagadnienie przymusu w oparciu o analizę działań, które nazywa mieszanymi. Bierze pod uwagę takie działania, które z jednej strony są dokonywane z powodu strachu przed większym złem lub z powodu czegoś pięknego (1110a4-5), z drugiej zaś jawią się jako działania realizowane pod przymusem ${ }^{19}$. Ich mieszany charakter wynika stąd, że: a) rozpatrywane same w sobie są niedobrowolne, ponieważ nikt ich nie wybiera dla nich samych (1110a19); b) rozpatrywane z punktu widzenia okoliczności, w których się je dokonuje, są dobrowolne, ponieważ są warte wyboru (ai $\rho \in T a ́)$ w konkretnym momencie i w zamian za osiągnięcie określonego rezultatu (1110b3-4); c) rozpatrywane z punktu widzenia ich zasady są dobrowolne, ponieważ pomimo determinant zewnętrznych są ostatecznie rezultatem działania zasady znajdującej się w podmiocie działającym ${ }^{20}$.

to postaci męstwa, które wchodzą w zakres przypadkowych homonimów (ảmò Túxๆs)

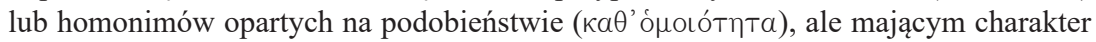
co najwyżej podobieństwa powierzchniowego. W tym sensie męstwo powodowane strachem przed karą nie byłoby męstwem lub byłoby granicznym przypadkiem męstwa. Na temat zagadnienia homonimiczności u Arystotelesa zob. Smolak (2013, s. 25-37).

18 W EN VI.13 Arystoteles wyróżnia cnotę naturalną (

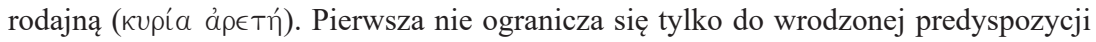
charakterologicznej, lecz może być również rozumiana jako cnota charakteru w formie wytrenowanego nabytku. Druga wskazuje na cnotę charakteru w pełnym tego słowa

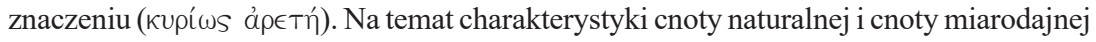
zob. Smolak (2013, s. 123-131).

19 Ponieważ w przypadku działań mieszanych zasada działania znajduje się w podmiocie działającym, więc takie działania nie są wprawdzie spowodowane przez zewnętrzną

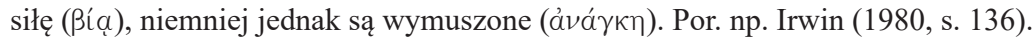

20 Zdaniem Bostocka (2000, s. 106), działania są mieszane dlatego, że podmiot działający z jednej strony chce realizować dane działanie, z drugiej zaś nie chce. Hursthouse (1984, s. 265) zauważa, że o mieszanym charakterze działań decyduje to, że z jednej strony są one warte unikania same w sobie, z drugiej zaś są warte wyboru w konkretnych okolicznościach i w danym momencie. Z kolei Irwin (1980, s. 136) sugeruje, że o mieszanym charakterze działań świadczy to, że podmiot działający jest zmuszony do 
Arystoteles podaje różne przykłady działań tego typu. Zwrócę uwagę na jeden z nich, który w sposób reprezentatywny wskazuje na dwa rysy dookreślające rozumienie dobrowolności z punktu widzenia działań, za które podmiot ponosi odpowiedzialność. Arystoteles opisuje zachowanie kapitana statku, który podczas sztormu wyrzuca ładunek za burtę, aby ocalić siebie i pasażerów.

Pierwszy rys jest rozwinięciem charakterystyki przedstawionej w punkcie b). Według kapitana wyrzucenie ładunku za burtę zasługuje na wybór za cenę uratowania siebie i innych. Wydaje się jednak, że czyn jest efektem uprzednio przeprowadzonej oceny sytuacji. Załóżmy, że mamy do czynienia z kapitanem, który zna się na swoim fachu. Taki kapitan nie wyrzuci ładunku pochopnie, lecz oszacuje, od którego momentu jego dalsze przewożenie stanie się niebezpieczne i zacznie zagrażać życiu jego oraz pasażerów. Wybierze więc właściwą chwilę (kaı ó́s; 1110a14), w której wyrzucenie ładunku za burtę jest konieczne ze względu na osiągnięcie zamierzonego celu. Można więc przyjąć, że kapitan działa na podstawie decyzji ${ }^{21}$. Oznacza to, że dokonuje przemyślanego wyboru spośród przedkładających się możliwości i realizuje to, co preferencyjnie wybrał22. Co prawda-jak podkreśla Arystoteles - każdy, kto ma rozum, zrobiłby to samo w tych konkretnych okolicznościach (1110a11), co zdaje się sugerować, że kapitan działa pod wpływem racjonalnego przymusu - musi to zrobić, jeśli chce ocalić siebie $\mathrm{i}$ innych ${ }^{23}$. Nie zmienia to jednak faktu, że działanie kapitana jest działaniem

podjęcia racjonalnego wyboru dokonania działania, które jest niezgodne z przyjętym przez niego racjonalnym planem.

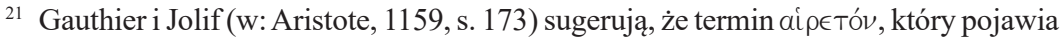
się w EN III.1 1110a12 w kontekście charakterystyki działań mieszanych, jest użyty przez Arystotelesa w zawężonym znaczeniu i odpowiada technicznemu znaczeniu terminu

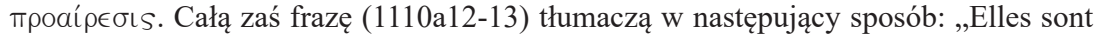
en effet, au moment précis où on les accomplit, des biens, au sens où est bien l'object de la decision" (Gaithier i Jolif, w: Aristote, 1958, s. 56).

22 Na temat $\pi \rho$ oai $\rho \in \sigma ı s$ zob. Smolak (2013, s. 82-90).

23 Przymus racjonalny zachodzi wtedy, gdy sprawca jest zmuszony dokonać wyboru między dwoma działaniami, z których jedno jest wyraźnie lepsze (por. Arnold, 2001, s. 56). Uratowanie życia swojego i innych jest wyraźnie lepsze od utraty dóbr materialnych. 
dobrowolnym, ponieważ to, co jest realizowane na podstawie decyzji, jest realizowane dobrowolnie ${ }^{24}$.

Drugi rys jest rozwinięciem pierwszego rysu oraz charakterystyki przedstawionej w punkcie c). Arystoteles sugeruje, że zasada ruchu części ciała kapitana znajduje się w nim, a nie poza nim. W tych zaś przypadkach, w których zasada ruchu znajduje się w nim, również od niego zależy, czy

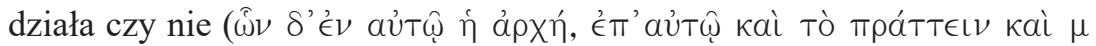
ท́; 1110a17-18).

Fragment 1110a17-18 wymaga jednak komentarza, ponieważ zdaje się kłaść nacisk przede wszystkim na zwrot „,zasada ruchu znajduje się w nim”. Kluczowe dla tego zwrotu jest pojęcie ảpxń w połączeniu z przyimkiem év. Sens zwrotu jest taki, że zasada działania znajduje się wewnątrz człowieka, a nie poza nim. Samo jednak pojęcie zasady wewnętrznej nie posiada odpowiedniej wartości eksplanacyjnej i nie zdaje sprawy z więzi zachodzącej między działaniem i sprawcą ${ }^{25}$. Istoty naturalne, a więc to wszystko, w czym

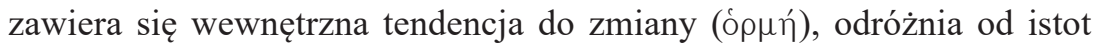

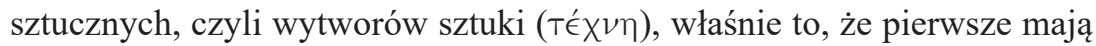
W sobie zasadę ruchu i spoczynku, a drugie nie ${ }^{26}$. Z tego jednak jeszcze nie wynika, że istota naturalna jest sprawcą swojego ruchu i spoczynku. Aby tak było, dane działanie musi zależeć od niej samej. Dlatego zwrot „od niego zależy, czy działa, czy nie” stanowi dopełnienie charakterystyki relacji działanie-sprawca.

Zwrot „od niego zależy, czy działa, czy nie” łączy w sobie dwa momenty. Pierwszy moment podkreśla, że przebieg wydarzeń, w jakich bierze udział sprawca, jest warunkowy - sprawca znajduje się w okolicznościach,

24 Jak podkreśla Arystoteles, ,decyzja jawi się jako to, co dobrowolne, chociaż nie jest tym samym, co dobrowolne - w każdym razie to, co dobrowolne, jest zakresowo szerszym pojęciem od decyzji, ponieważ nawet dzieci oraz zwierzęta mają udział w tym, co dobrowolne, ale nie mają udziału w decyzji” (EN III.2 1111b6-9).

25 Por. przyp. 11.

26 Por. Ricoeur (1990, s. 112-113). Jak zauważa Arystoteles w Fizyce II.8 199a1516, sztuka wykańcza to, czego natura nie może wykonać. Na przykład wytwory pracy szewca uzupełniają naturę, ponieważ buty ułatwiają człowiekowi przemieszczanie się w świecie, w którym żyje. Buty mają więc wartość użytkową i nie zawierają w sobie zasady ruchu oraz spoczynku. 
które dopuszczają różne możliwe przebiegi wydarzeń ${ }^{27}$. Drugi moment podkreśla, że jest w mocy sprawcy dokonanie lub zaniechanie działania sprawca jest władny modyfikować przebieg wydarzeń i twórczo odnosić się do otaczającego świata, w ramach możliwości wyznaczonych przez sytuację, w jakiej się znajduje. O ile pierwszy moment podkreśla, że sprawca znajduje się w obliczu przedkładających się możliwości działania, o tyle drugi moment akcentuje, że sprawca nie tylko ma możliwość wyboru, lecz również rozporządza zdolnością sprawienia czegoś w świecie.

Gdy więc od podmiotu zależy, czy działa, czy nie, to jest to równoznaczne z tym, że zasada działania znajduje się w nim. Ale z tego, że zasada działania znajduje się w nim, nie wynika jeszcze, że działanie zależy od niego. Jak podkreśla Arystoteles w Etyce eudemejskiej [EE] II.8 1225a27-30, nie przypisujemy ludziom natchnionym i prorokom sprawstwa działania, ponieważ nie od nich zależy wypowiadanie tego, co powiedzieli i robienie tego, co zrobili, jakkolwiek to, co z nich wyszło, jest efektem pracy ich myślenia i części ciała. A zatem nawet, jeśli zasada działania znajduje się $\mathrm{w}$ podmiocie, to nie jest to równoznaczne z tym, że od podmiotu zależy, czy działa, czy nie.

Tym, co spaja oba zwroty, jest decyzja. Można to też wyrazić w ten sposób, że oba zwroty dookreślają decyzję. Decyzja jest bowiem wewnętrzną

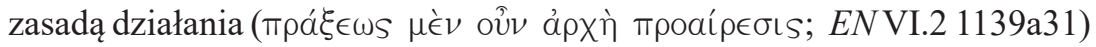
i równocześnie dotyczy tego, co zależy od nas (III.2 1111b30). Zatem to przede wszystkim decyzja oznacza, czym jest dobrowolność z punktu widzenia działań, za które podmiot ponosi odpowiedzialność. W istocie, ten, kto działa na podstawie decyzji, kontroluje swoje działanie i sprawuje nad nim władzę, zachowując gotowość do jego rewizji pod wpływem nowych danych. I ten fakt podkreśla przyimek émí. Dlatego to, na co się decydujemy, podlega ocenie i zasługuje na pochwałę lub naganę. W konsekwencji jesteśmy odpowiedzialni za działania dokonywane na podstawie decyzji ${ }^{28}$.

27 Należy zaznaczyć, że Meyer (2006, s. 138) przestrzega przed błędnym rozumie-

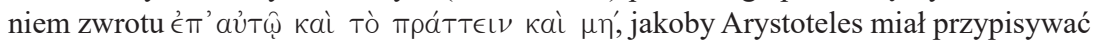
sprawcy rodzaj wolności do działania inaczej.

${ }_{28}$ Zdaniem Irwina (1980), Arystoteles wyróżnia prostą (simple) i bardziej złożoną (more complex) teorię odpowiedzialności. W myśl pierwszej, dobrowolność nie wymaga deliberacji, w myśl drugiej, deliberacja jest nieodłączna od odpowiedzialności. Ponieważ decyzja pozostaje w ścisłym związku z deliberacją (por. np. EE II.10 1226b6-9; EN III.2 1112a15-17; Etyka wielka I.17 1189a32-1189b1), więc jak podkreśla Irwin (s. 132): 
Można więc przyjąć, że człowiek jest sprawcą działania, gdy jest to jego własne działanie, czyli gdy on sam jest jego auctor agendi. Jest zaś auctor agendi danego działania, gdy jest to działanie podjęte na podstawie jego własnej decyzji. Jest to jednak możliwe, gdy zasada działania znajduje się w nim i od niego zależy, czy działa, czy nie. W istocie, paradygmatycznym sprawcą działania jest taki podmiot, w przypadku którego wewnętrzną zasadą działania jest jego własna decyzja.

\section{Które działanie jest działaniem odpowiedzialnym}

Czy z tego, że podmiot działający jest w uzasadniony sposób odpowiedzialny za to, co robi, wynika, że jego działanie jest działaniem odpowiedzialnym? Nie wynika, ponieważ można być odpowiedzialnym za działanie, które jest nieodpowiedzialne. Nie każde więc działanie, za które auctor agendi jest odpowiedzialny, jest zarazem odpowiedzialnym działaniem. I Arystoteles godzi się na takie rozróżnienie, gdy zauważa, że jedne działania zasługują na naganę, inne zaś - na pochwałę.

Głównym przedmiotem zainteresowania Arystotelesa w Etykach jest określenie celu ludzkiego życia i wykazanie, w jaki sposób można go osiągnąć. W związku z tym Arystoteles przeprowadza badanie, które zmierza do ustalenia, czym jest najwyższe z dóbr możliwych do osiągnięcia przez ludzkie działanie (EN I.4 1095a16). Co do jego nazwy, panuje powszechna zgoda, ponieważ zarówno ludzie prości, jak i wykształceni, określają je eudaimonia (1095a17). Nie ma już jednak takiej zgody, gdy chodzi o odpowiedź na pytanie, czym jest eudaimonia (1095a20) i jaki sposób życia jest najbardziej eudaimoniczny (I.5 1095b15). Jedni widzą eudaimonię w życiu hedonistycznym, inni w życiu skoncentrowanym na aktywności politycznej,

„A jest odpowiedzialny za działanie ' $x$ ' wtedy i tylko wtedy, gdy (a) A jest zdolny do podjęcia skutecznej decyzji, aby wykonać działanie ' $\mathrm{x}$ ', $\mathrm{i}$ (b) A działa dobrowolnie (,A is responsible for doing $\mathrm{x}$ if and only if (a) $\mathrm{A}$ is capable of deciding effectively about $\mathrm{x}$, and (b) A does x voluntarily"). Irwin (s. 142) zwraca również uwagę, że bardziej złożona teoria pozwala zrozumieć: i) dlaczego Arystoteles uważa, że tylko niektóre podmioty, które działają dobrowolnie, ponoszą odpowiedzialność za to, co robią; ii) dlaczego dobrowolne działanie jest zazwyczaj działaniem, za które podmiot ponosi odpowiedzialność. 
jeszcze inni w życiu zogniskowanym na aktywności teoretycznej (ßíos ảm

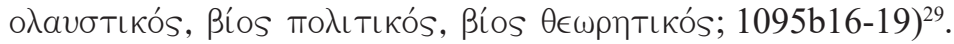

Arystoteles nie akceptuje pierwszej wykładni eudaimonii, ponieważ ci, którzy zabiegają o przyjemności, mylnie interpretują naturę ludzką i wybierają życie charakterystyczne dla istot niższych od człowieka (1095b20). Natomiast drugiej i trzeciej nie odrzuca i w toku analiz w kolejnych partiach $E N$ dochodzi ostatecznie do wniosku, że oba sposoby życia mają charakter eudaimoniczny. Zastrzega wprawdzie, że aktywność polityczna jest drugorzędną formą eudaimonii w stosunku do aktywności teoretycznej (X.8 1178a9-10), ale jej nie deprecjonuje. W istocie, aktywność polityczna jest formą praktyki, która stwarza optymalne warunki do urzeczywistnia-

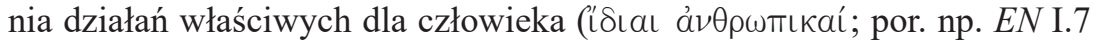
1097b34), czyli partycypowania w rządzeniu mó入ıs, a także prowadzenia rozmów i deliberacji we współżyciu oraz wspólnocie ${ }^{30}$. Wyższość aktywności teoretycznej polega na tym, że pozwala na uczestniczenie w boskości, ponieważ jej spełnianie zakłada aktywizację rozumu (voûs), czyli elementu boskiego w nas (X.7 1177b27-31).

Wydaje się więc, że działania człowieka są działaniami odpowiedzialnymi, gdy jego życie jest najbardziej właściwe i udane, czyli eudaimoniczne. Już wiadomo, że jesteśmy odpowiedzialni za działania dokonywane na podstawie decyzji. Wiadomo też, że paradygmatycznym auctor agendi jest taki podmiot, w przypadku którego wewnętrzną zasadą działania jest jego własna decyzja. Ale z tego, że podmiot działa na podstawie decyzji, nie wynika jeszcze, że jego działania są działaniami odpowiedzialnymi.

Kanonicznym przypadkiem człowieka, który działa na podstawie decy-

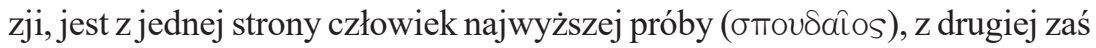
człowiek o spaczonym charakterze (какós). Obaj bowiem osiągnęli poziom wewnętrznego scalenia, który świadczy o zharmonizowaniu racjonalnej

${ }^{29}$ W EE I.4 1215b34-1215b1 Arystoteles zaznacza, że są trzy największe ludzkie

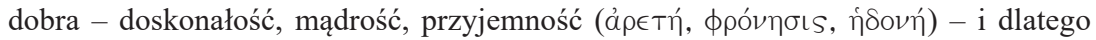
każdy człowiek, jeśli ma tylko sposobność wyboru, decyduje się na życie polityczne,

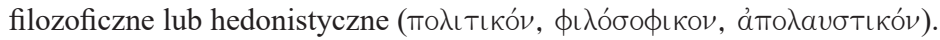

${ }^{30}$ Człowiek jest istotą obywatelską i z natury skłonną do życia wespół z innymi ( $\zeta \hat{\omega}$

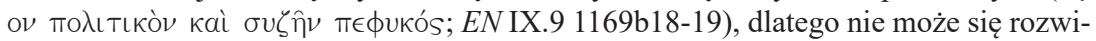

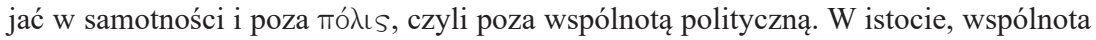
polityczna jest horyzontem, w którym toczy się całe życie człowieka i rozstrzygają się wszystkie ludzkie sprawy (por. Pańpuch, 2015, s. 213). 
i zmysłowo-orektycznej części duszy oraz wykrystalizowaniu się centrum decyzyjnego ${ }^{31}$, choć - co trzeba wyraźnie podkreślić - innego typu u każdego z nich. Człowiek najwyższej próby ma pozytywnie wartościowe centrum decyzyjne, ponieważ nie tylko wie, jaki rodzaj życia jest dla człowieka najbardziej eudaimoniczny, ale równocześnie realizuje go w praktyce. Człowiek o spaczonym charakterze ma negatywnie wartościowe centrum decyzyjne, ponieważ nie tylko nie wie, jaki rodzaj życia jest dla człowieka najbardziej eudaimoniczny, lecz równocześnie planuje swoje życie pod kątem realizacji złego celu życiowego ${ }^{32}$. Tak więc z punktu widzenia przyjętej przez Arystotelesa treściowej wykładni najwyższego dobra możliwego do osiągnięcia przez człowieka należałoby przyjąć, że wprawdzie obaj są sprawcami swoich działań i obaj ponoszą odpowiedzialność za to, co robią, ale działania pierwszego są działaniami odpowiedzialnymi, natomiast działania drugiego są działaniami nieodpowiedzialnymi. Które więc działania są działaniami odpowiedzialnymi?

Gdy Arystoteles przystępuje do opracowania definicji cnoty charakteru (EE II.10; EN II.6), zauważa, że cnota charakteru jest dyspozycją proairetycz-

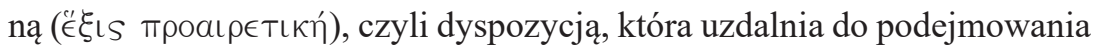
decyzji. Wprawdzie również wada charakteru jest dyspozycją proairetyczną, ale cnota charakteru różni się od wady charakteru tym, że uzdalnia do podejmowania decyzji w taki sposób, iż podmiot działający postępuje ze

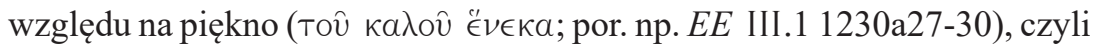
ze względu na to, co nakazałby rozum w funkcji praktycznej (1229a2) ${ }^{33}$. Ponieważ Arystoteles podkreśla, że dane działanie jest wykonywane zgodnie z cnotą charakteru, gdy podmiot działający decyduje się na nie z powodu niego samego (Sı' aủTóv; EN II.6 1105a31-32; VI.12 1144a16-20), więc są podstawy, aby sądzić, że działanie wykonywane ze względu na piękno jest odpowiednikiem działania zgodnego z cnotą charakteru, na które decydujemy z powodu niego samego. Co może jednak oznaczać, że działanie

31 Na takie centrum zdaje się zwracać uwagę Price (1989, s. 105). Na temat centrum decyzyjnego zob. Smolak (2013, s. 137-138).

${ }^{32} \mathrm{~W}$ przypadku człowieka o spaczonym charakterze również zachodzi harmonia między zmysłowo-orektyczną i racjonalną częścią duszy, z tym, że jego centrum decy-

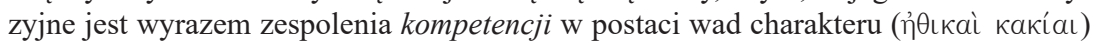

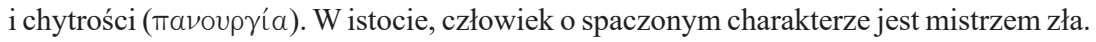

33 Na temat charakterystyki cnoty i wady charakteru jako dyspozycji proairetycznych zob. Smolak (2013, s. 80-97). 
wykonywane zgodnie z cnotą charakteru jest typem działania, na które decydujemy się z powodu niego samego, ergo ze względu na piękno lub, jak inaczej stwierdza Arystoteles, dlatego, że jest piękne (ÖTı кa入óv; np. EN III.7 1116a12)?

Jedni komentatorzy sądzą, że stwierdzenie „decydować się na działanie zgodne z cnotą charakteru z powodu niego samego" jest mylące, ponieważ Arystotelesowi chodzi przede wszystkim o podkreślenie faktu, iż ten, kto decyduje się na działanie tego typu, dąży do osiągnięcia rezultatu, odpowiedniego dla tego działania, z jego powodu, a nie z powodów ubocznych ${ }^{34}$. Jeżeli więc podmiot działający decyduje się na działanie zgodne z cnotą charakteru, to czyni tak, aby osiągnąć określony cel, który jednak nie zawiera się w samym działaniu, lecz jest jego rezultatem. Ktoś, kto decyduje się na przykład na działanie zgodne z cnotą męstwa, czyni tak nie ze względu na samo mężne działanie lub nie tylko ze względu na nie, lecz przede wszystkim dlatego, że zależy mu na tym, aby doprowadzić do urzeczywistnienia określonego rezultatu - zależy mu na tym, aby zabezpieczyć własną mó $ı$ ıs przed najazdem wroga. Nikt przecież, jak zauważa Arystoteles, nie decyduje się na wojowanie ze względu na samo wojowanie, chyba że jest kimś krwiożerczym (EN X.7 1177b9-11). Z tego punktu widzenia, decydować się na działanie zgodne z cnotą charakteru z powodu niego samego, oznaczałoby mieć przede wszystkim na względzie dobro konkretnej wspólnoty lub konkretnych członków wspólnoty ${ }^{35}$ i dążyć do realizacji tego celu dla niego samego, a nie z ukrytych powodów. Jeżeli ktoś naraża się na rany, a nawet na śmierć po to, aby zapewnić bezpieczeństwo swojej rodzinie, przyjaciołom czy obywatelom, i czyni to ze względu na ich bezpieczeństwo, a nie po to lub nie tylko po to, aby na przykład zasłużyć na zaszczyty, to cel jego działania jest piękny i jego działanie spełnia wymogi działania realizowanego ze względu na piękno (por. np. EN IX.8 1169a18-25). Zatem o pięknie działania rozstrzygałby cel i sposób, w jaki sprawca zmierza do jego osiągnięcia.

Inni komentatorzy uważają, że w stwierdzeniu „decydować się na działanie zgodne z cnotą charakteru z powodu niego samego" Arystotelesowi chodzi o to, iż wartość działania zgodnego z cnotą charakteru nie zależy od rezultatu, jaki dzięki temu działaniu zostaje osiągnięty, lecz od tego, czym

${ }^{34}$ Por. np. Whiting (2002, s. 280).

35 Por. np. Irwin (1996). 
takie działanie jest, tzn. od przysługujących mu własności, które sprawiają, że jest ono warte wyboru samo w sobie. W EN I.1 1094a3-5 Arystoteles zauważa, że jedne cele są tożsame $\mathrm{z}$ działaniami, natomiast inne cele są tożsame z wytworami. Dystynkcja pozostaje w ścisłym związku z podziałem

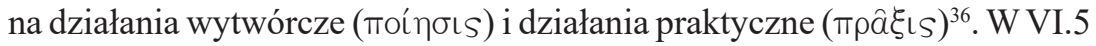
Arystoteles podkreśla, że działanie wytwórcze tym różni się od działania praktycznego, że cel pierwszego jest różny od samego działania wytwórczego, natomiast cel drugiego nie jest różny od samego działania praktycznego, ponieważ jest nim dobre działanie praktyczne $(\epsilon \cup ̉ \pi \rho \alpha \xi \dot{\xi} \alpha)^{37}$. Tak więc dobre działania praktyczne wchodzą w zakres działań autotelicznych, czyli takich, które są warte wyboru dla nich samych. Ich wewnętrzna wartość zależy od tego, że posiadają cechy, które sprawiają, że są one czymś pięknym. O jakie cechy może chodzić?

W Met XIII.3 Arystoteles podkreśla, że najważniejszymi formami piękna są porządek, proporcjonalność i określonośćc ${ }^{38}$. Biorąc pod uwagę formalne wyznaczniki piękna, należałoby przyjąć, że istotą działania realizowanego ze względu na piękno jest jego uporządkowanie, proporcjonalność

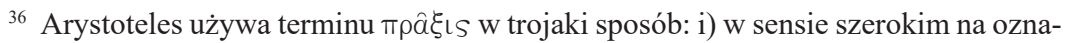

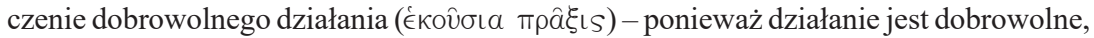
gdy jego zasada tkwi w podmiocie działającym, więc $\pi \rho \hat{a} \xi$ ıs w sensie szerokim mogą realizować dzieci i zwierzęta bezrozumne (por. przyp. 23); ii) w sensie węższym na

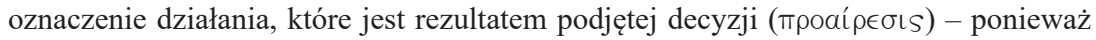
decyzja jest nierozerwalnie związana z deliberacją, więc do $\pi \rho \hat{a} \xi ı$ w sensie węższym nie są zdolne zwierzęta bezrozumne; iii) w sensie najwęższym na oznaczenie praktycznego działania, które jest nie tylko podjęte na podstawie decyzji, lecz również jest działaniem, które jest swoim własnym celem.

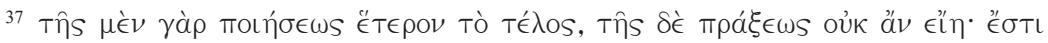

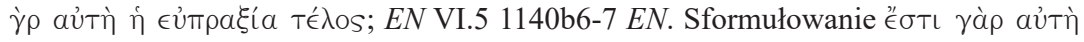

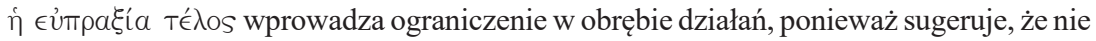
dowolna $\pi \rho \hat{\alpha} \xi ı$ jest swoim celem, lecz tyko $\in \dot{\pi} \pi \rho \alpha \xi \dot{\xi}$ a. Takie ograniczenie może budzić zastrzeżenie, skoro działania człowieka o spaczonym charakterze (кakós) również mogą być autoteliczne. Jest to jednak pozorne zastrzeżenie, ponieważ Arystotelesowi chodzi przede wszystkim o działania, które są równocześnie konstytutywnymi składnikami eudaimonii. Tymczasem działania człowieka o spaczonym charakterze nie spełniają warunków nałożonych na działanie eudaimoniczne, tzn. na działanie eudaimoniczne w rozumieniu Arystotelesa.

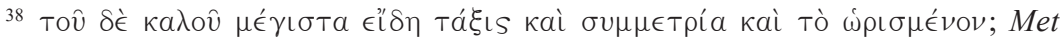
XIII.3 1078a36-1078b1. 
i określoność ${ }^{39}$. Z tego punktu widzenia o pięknie działania rozstrzygałby nie tyle cel, do którego ono zmierza, lecz raczej jego kompozycja lub, inaczej rzecz ujmując, jego forma ${ }^{40}$.

Ale są też tacy komentatorzy, którzy sugerują, że decydowanie się na działanie zgodne z cnotą charakteru z powodu niego samego odzwierciedla motyw, którym kieruje się podmiot działający ${ }^{41}$. W ,argumencie z funkcji” Arystoteles sugeruje, że to przede wszystkim człowiek najwyższej próby spełnia w sposób perfekcyjny właściwą dla człowieka funkcję (EN I.7 1098a12-14) $)^{42}$. Tymczasem człowiek najwyższej próby odznacza się tym, że motywem jego działania jest piękno.

W EE VIII.3 Arystoteles odróżnia człowieka dobrego (ảyatós) od

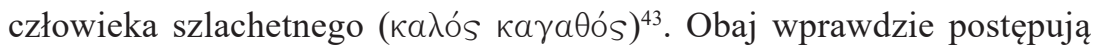
zgodnie z cnotami charakteru. Ale ảya $\theta$ ós ma błędne przekonanie na temat tego, czym jest eudaimonia i jaką rolę odgrywa cnota charakteru. Uważa bowiem, że właściwym obiektem ludzkiego dążenia są dobra naturalne i że poprzez realizowanie działań zgodnych z cnotami charakteru takie dobra pozyska. Stąd działania człowieka dobrego są wprawdzie piękne, ale tylko przypadkowo (1249a15-16). Są piękne, ponieważ są zgodne z cnotami charakteru, są przypadkowo piękne, ponieważ są podejmowane z powodu

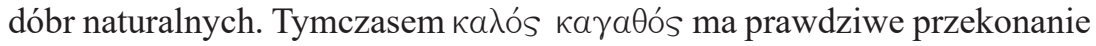
na temat tego, czym jest eudaimonia, ponieważ uważa, że działania zgodne z cnotami charakteru są konstytutywnymi składnikami eudaimonii. Dlatego jego działania są piękne w sobie, a nie przypadkowo. W istocie, szlachet-

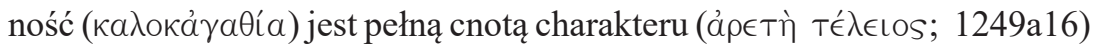
i odzwierciedla doskonale ukształtowany charakter, ponieważ jej podbudowę stanowią konkretne cnoty charakteru (1248b10). Zarazem obecność szlachetności sprawia, że cnoty charakteru, które są jej fundamentem ontycznym, są w pełni rozwinięte. Oznaką tego jest fakt, że w przypadku podmiotu, którego charakteryzuje szlachetność, motywem jego działania w dziedzinie charakterystycznej dla każdej z cnót charakteru - jest piękno.

39 Formalistyczne rozumienie wyznaczników piękna w kontekście działania zgodnego z cnotą charakteru postuluje np. Cooper (1999, s. 273-276).

40 Por. np. Korsgaard (1996).

41 Por. np. Irwin (w: Aristotle, 1985, s. 312).

42 Na temat ,argumentu z funkcji” zob. Smolak, Łacina (2015).

$43 \mathrm{Na}$ temat różnicy między dobrym i szlachetnym człowiekiem zob. Smolak (2013, s. 132-138). 
Można zatem przyjąć, że człowiek szlachetny, ergo człowiek najwyższej próby ${ }^{44}$, jest pięknym sprawcą działania, ponieważ w paradygmatyczny sposób ujawnia, co to znaczy decydować się na działanie zgodne z cnotą charakteru z powodu niego samego.

Przedstawione wykładnie stwierdzenia „decydować się na działanie zgodne z cnotą charakteru z powodu niego samego" wzajemnie się dopełniają, ponieważ wskazują na różne strony ludzkiego działania, które zarazem łączy wspólny mianownik, czyli piękno. Stwierdzenie może bowiem podkreślać, że: i) piękny jest cel, który ma być osiągnięty przez działanie - jest on piękny, ponieważ jego realizacja przysparza dobra innym (por. np. Retoryka, I.9 1366a36-b4); ii) piękne jest samo działanie - jest ono piękne, ponieważ jest warte wyboru z powodu niego samego, nawet jeżeli nic z niego nie wynika (por. np. EN I.7 1097b3-4); iii) piękny jest sprawca działania - jest on piękny, ponieważ jest on człowiekiem najwyższej próby, czego wyrazem jest to, że motywem jego działania jest piękno (por. np. EN IX.8 1169a31-32).

Ale wzajemne dopełnianie się przedstawionych sposobów rozumienia stwierdzenia ,decydować się na działanie zgodne z cnotą charakteru z powodu niego samego", znajduje swoje dodatkowe potwierdzenie jeszcze w inny sposób. W Met V.16 1021b16-25 Arystoteles podaje trzy podsta-

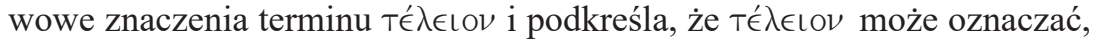
że dana rzecz jest: i) kompletna, ponieważ posiada wszystkie właściwe dla siebie części; ii) doskonała, ponieważ posiada właściwą dla siebie perfekcję (ảp€Tท́); iii) ostateczna, ponieważ jest spełniona, czyli zrealizowała właściwy dla siebie cel.

Ponieważ o pięknie działania zgodnego z cnotą charakteru rozstrzyga nie tylko jego forma, lecz również to, że cel, do którego zmierza, zostaje zrealizowany i to zrealizowany nie przypadkowo, lecz w sposób zamierzony i to zamierzony z jego powodu, więc można przyjąć, że zewnętrzny rezultat, który kończy działanie tego typu, nie jest obojętny z punktu widzenia najwyższego dobra możliwego do osiągnięcia przez człowieka, czyli eudaimonii. Nie chodzi więc tylko o samo działanie, lecz również o doprowadzenie do

${ }^{4}$ Ponieważ w EE VIII.3 Arystoteles określa człowieka szlachetnego nie tylko przy

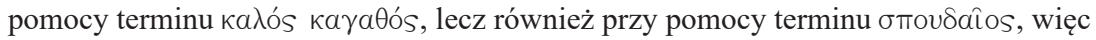
są podstawy, aby oba terminy traktować synonimicznie i przez człowieka szlachetnego rozumieć człowieka najwyższej próby. 
urzeczywistnienia zamierzonego celu. Jego nieosiągnięcie skutkuje tym, że podjęte działanie pozostaje niejako niedomknięte. $Z$ tego jednak nie wynika, że brak zrealizowania zamierzonego celu obniża wartość działania zgodnego z cnotą lub sprawia, że jest ono jej pozbawione. O ile działanie wytwórcze jest w oczywisty sposób mniej warte niż jego rezultat, a w przypadku, gdy kończy się fiaskiem, w zasadzie nie ma wartości, o tyle w przypadku dobrego działania praktycznego tak nie jest. Nieurzeczywistnienie zamierzonego rezultatu nie sprawia, że działanie staje się bezwartościowe. Nawet wtedy jest

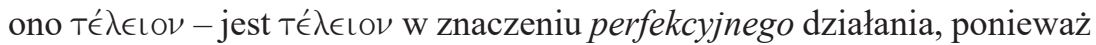
jest realizowane zgodnie z przynależną do niego cnotą charakteru. Jeżeli natomiast zostaje ono dopełnione realizacją tego, co zostało zamierzone, to staje się ono Té $\lambda \epsilon \iota \mathrm{V}$ nie tylko w znaczeniu perfekcyjnego działania, lecz również w znaczeniu kompletnego działania.

Ale również o sprawcy działania, który działa zgodnie z cnotą charakteru w pełnym tego słowa znaczeniu, można powiedzieć, że jest Té $\lambda \epsilon \iota \mathrm{S}$, i to bez względu na to, czy jego działanie jest jedynie Té $\lambda \in \operatorname{L} \nu$ w znaczeniu

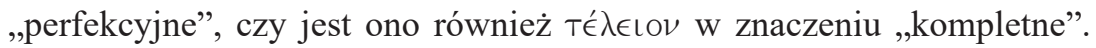
Taki sprawca jest bowiem spetniony ( $(\epsilon ́ \lambda \in \operatorname{los}$; EE, VII.2 1237a30) - jest spetniony, ponieważ osiągnął cel w samorozwoju (ÖTı кaì $\tau \in \lambda \in \iota \omega \theta \in ́ \nu T \iota$; 1237a29). O takim sprawcy Arystoteles powie, że jest całkowicie dobry

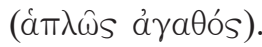

Gdy Arystoteles określa coś jako całkowicie dobre, chodzi mu przede wszystkim o to, że to coś urzeczywistnia wymagania standardu w swoim rodzaju. Tymczasem w ramach praktyki działania, takim standardem jest człowiek najwyższej próby. Dlaczego? Ponieważ cechuje go umiejętność dostrzegania prawdy w przypadku każdego obiektu chcenia i formułowania trafnej oceny na jego temat (EN I.13 1113a29-30). W istocie, człowiek naj-

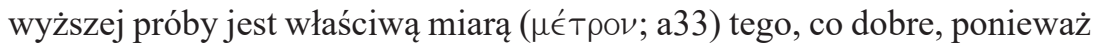
ze względu na swoją konstytucję potrafi ocenić, co jest dobre niezależnie od tego, w jakiej relacji on sam pozostaje do ocenianego dobra. Jeżeli więc ceni cnoty charakteru dla nich samych i jeżeli uważa, że działania zgodne z nimi stanowią konstytutywne składniki eudaimonii, to jest tak dlatego, że to, co jemu jawi się jako dobre, jest takie faktycznie. W efekcie człowiek najwyższej próby będzie również właściwą miarą działania, które jest działaniem odpowiedzialnym. Jest on bowiem właściwym kandydatem 
na eudaimona ${ }^{45}$. A ponieważ człowiek najwyższej próby decyduje się na działanie zgodne z cnotą charakteru z powodu niego samego, więc można przyjąć, że odpowiedzialne działanie to działanie, które jest podjęte na podstawie decyzji i ze względu na piękno.

\section{Zamiast zakończenia}

We Wstępie zaznaczyłem, że Arystoteles porusza problematykę odpowiedzialności głównie z perspektywy odpowiedzialności rozumianej negatywnie, czyli odpowiedzialności w sensie imputacji. Ale zasygnalizowałem również, że człowiek w ujęciu Arystotelesa jest istotą obywatelską i z natury skłonną do życia wespół z innymi ${ }^{46}$. Stąd w zakres jego troski o eudaimonię wchodzi również dbałość o dobro Tó $ı$ s oraz jej obywateli ${ }^{47}$. W tym sensie, obok odpowiedzialności rozumianej negatywnie, przez rozważania Arystotelesa przebija również odpowiedzialność responsoryczna. Wykazanie zasadności tego przypuszczenia wykracza jednak poza ramy niniejszego artykułu.

\section{Bibliografia}

Aristote (1958). L'Éthique à Nicomaque. T. I: Introduction et Traduction par R.A. Gauthier et J.Y. Jolif. Louvain: Publications Universitaires.

45 Trzeba jednak pamiętać, że z faktu, iż ktoś jest najwyższej próby, nie wynika jeszcze, że jest eudaimonem. Może się przecież zdarzyć, że człowieka najwyższej próby dotyka choroba lub jakieś niepowodzenie. Jak podkreśla Arystoteles, „ci, którzy twierdzą, że ten, kto jest torturowany lub kogo spotkała wielka niepomyślność, jest eudaimonem, o ile jest dobrym człowiekiem, mówią, chcąc nie chcąc, od rzeczy" (ENVII.13 1153b19-21). Co prawda człowiek najwyższej próby zachowuje się pięknie w każdych okolicznościach, a więc również w obliczu niepowodzeń, ale, jak podkreśla Arystoteles, eudaimonia jest realizowana w przeciwnych warunkach (Polityka VII.13 1332a20-21). Dlatego również człowiek najwyższej próby potrzebuje dóbr cielesnych i dóbr zewnętrznych, aby ich brak nie przeszkadzał mu w podejmowaniu i realizowaniu aktywności eudaimonicznych (EN VII.13 1153b17-19).

46 Por. przyp. 30.

47 Jak zauważa Berti (2016, s. 193), Arystoteles pojmuje sprawowanie władzy jako służbę $(\lambda \in \iota$ Toup $\gamma \in \hat{\imath} \nu)$. Zatem ten, kto sprawuje władzę, powinien troszczyć się o dobro innych. 
Aristote (1959). L'Éthique à Nicomaque. T. II: Commentaire par R.A. Gauthier et J.Y. Jolif J.Y., partie 1. Louvain: Publications Universitaires.

Aristoteles (1960). Aristotelis Opera ex recognition I. Bekkeri, edition altera quam curavit O. Gigon. Berolini.

Aristotle (1985). The Nicomachean Ethics. Transl. with Commentaries and Glossary by T. Irwin. Indianapolis: Hackett Publishing Company.

Arnold, D.G. (2001). Coercion and Moral Responsibility. American Philosophical Quarterly, 38, 53-67.

Bondeson, W. (1974). Aristotle on Responsibility for One's Character and the Possibility of Character Change. Phronesis, 19, 59-65.

Bostock, D. (2000). Aristotle's Ethics. New York: Oxford University Press.

Cooper, J.M.C. (1999). Reason and Emotion: Essays on Ancient Moral Psychology and Ethical Theory. Princeton: Princeton University Press.

Galewicz, W. (2003). Z Arystotelesem przez greckie tragedie. Cz. 2: O bładzeniu, przymusie i dobrowolności. Kraków: Wydawnictwo Literackie.

Hursthouse, R. (1984). Acting and Feeling in Character: Nicomachean Ethics 3.i. Phronesis, 29.

Irwin, T.H. (1980). Reason and Responsibility in Aristotle. W: A.O. Rorthy (red.), Essays on Aristotle's Ethics (s. 117-155). Berkeley-Los Angeles: University of California Press.

Irwin, T.H. (1996). Ethics in the 'Rhetoric' and in the 'Ethics'. W: A.O. Rorthy (red.), Essays on Aristotle's 'Rhetoric' (s. 142-174). Berkeley-Los Angeles: University of California Press.

Korsgaard, Ch.M. (1996). From Duty and for the Sake of the Noble: Kant and Aristotle on Morally Good Action. W: S. Engstrom, J. Whiting (red.), Aristotle, Kant, and the Stoics. Rethinking Happiness and Duty (s. 203-236). New York: Cambridge University Press.

Moline, J.N. (1989). Aristotle on Praise and Blame. Archiv für Geschichte der Philosophie, 71 (3), 283-302.

Meyer, S.S. (2006). Aristotle on the Voluntary. W: R. Kraut (red.), The Blackwell Guide to Aristotle's Nicomachean Ethics (s. 137-157). Oxford: Blackwell Publishing.

Pańpuch, Z. (2015). Szczęście a polityka. Aretologiczne podstawy politologii Platona i Arystotelesa. Lublin: Wydawnictwo KUL. 
Price, A.W. (1989). Love and Friendship in Plato and Aristotle. Oxford: Oxford University Press. Ricoeur, P. (1990). Soi-même comme un autre. Paris: Editions du Seuil.

Smolak, M. (2013). Przyjaźń w świetle etyki Arystotelesa. Kraków: Wydawnictwo Uniwersytetu Jagiellońskiego.

Smolak, M., Łacina, K. (2015). Argument z funkcji - Etyka nikomachejska, 1.7, 1097b22-1098a17. W: K. Bałękowski, K. Maciąg (red.), Filozoficzne rozważania o człowieku, wolności i wartościach, Lublin: Fundacja na rzecz promocji nauki i rozwoju TYGIEL.

Wesoły, M. (2012). Dusza żywienna (wegetatywna) zwierząt w koncepcji Arystotelesa. W: K. Ilski (red.), Człowiek w świecie zwierząt-zwierzęta w świecie człowieka (s. 87-106). Poznań: Wydawnictwo Naukowe UAM.

Whiting, J. (2002). Eudaimonia, External Results, and Choosing Virtuous Actions for Themselves. Philosophy and Phenomenological Research, 65, 270-290.

\section{ARISTOTLE ABOUT THE AGENT AND THE RESPONSIBLE ACTION}

\section{Summary}

At EN III.1 1109b31-32 Aristotle says we praise and censure voluntary actions and we feel sympathy for involuntary actions, and sometimes even pity. Next he examines which actions are voluntary and involuntary. This examination is connected with determination of the conditions under which the person is auctor agendi and thus can respond for the action. But it is not right to say, when somebody is auctor agendi his action is responsible. Hence, to answer to the question which action is responsible action in Aristotle, the author considers the issue in two stages. The first stage is devoted to clarification what does it mean to be the agent of action. The second stage gives the explanation of what does it mean "to decide for the action accordance with virtue because of it". As the result, the author demonstrates that the responsible action is taken on the basis of decision and for the sake of fine. He shows such action is fine because: a) the realized end is fine; b) it is choiceworthy in itself; c) the motive of the agent is the fine. 